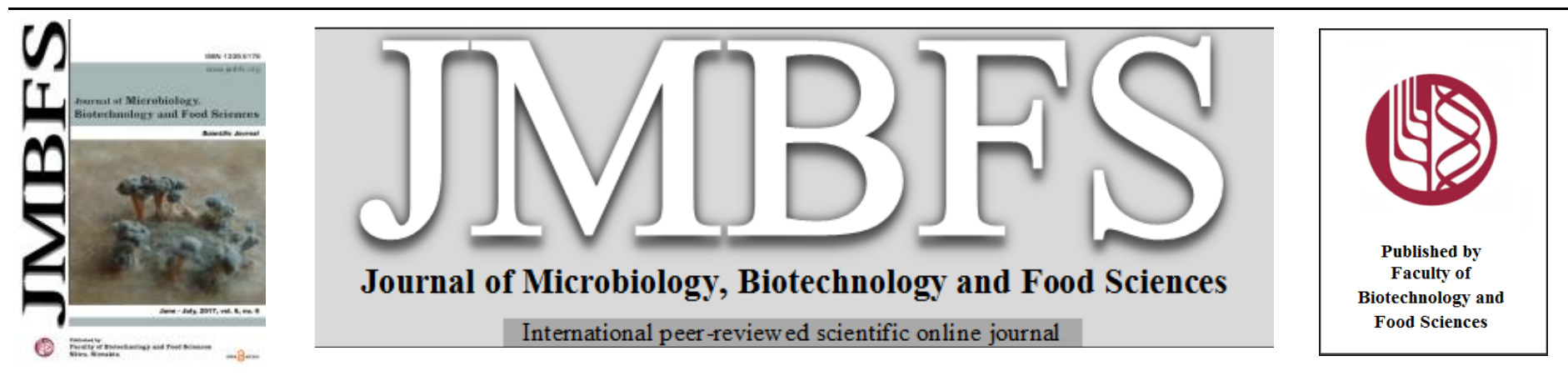

\title{
ENHANCED AMYLOLYTIC ACTIVITY OF INTRACELLULAR $\alpha$-AMYLASE PRODUCED BY BACILLUS TEQUILENSIS
}

\author{
${ }^{1}$ Prasanth Manohar, ${ }^{1}$ Shanthini T, ${ }^{2}$ Kodiveri Muthukalianan Gothandam, ${ }^{3}$ Velu Rajesh Kannan, ${ }^{1 *}$ Nachimuthu Ramesh \\ $\operatorname{Address}(e s):$ \\ ${ }^{1}$ Department of Biomedical Sciences, School of Biosciences and Technology, VIT University, Vellore, Tamil Nadu, India. \\ ${ }^{2}$ Department of Biotechnology, School of Bio Sciences and Technology, VIT University, Vellore, Tamil Nadu, India. \\ ${ }^{3}$ Department of Microbiology, Bharathidasan University, Tiruchirappalli, Tamil Nadu, India.
}

*Corresponding author: drpnramesh@gmail.com

doi: $\underline{10.15414 / j m b f s .2017 .6 .6 .1314-1318}$

\section{ARTICLE INFO}

Received 14.6. 2016

Revised 14. 5. 2017

Accepted 15. 5. 2017

Published 1. 6. 2017

Regular article

OPEN OACCESS $_{\text {Act }}$

\begin{abstract}
The amylolytic enzyme plays a very important role in industrial applications. This study aimed to screen amylase producing Bacillus sp. and to promote its amylolytic activity by mutagenesis. Samples were collected from coastal mud samples and starch hydrolyzing isolates were screened. A single isolate having the highest enzyme activity was identified as Bacillus tequilensis by 16S rRNA analysis. A starch medium was optimized and fermentation period studies revealed that the mutant strain (after $60 \mathrm{sec}$ of UV exposure) had higher activity $(868 \mathrm{U} / \mathrm{mL} / \mathrm{min})$ than the parental strain $(418 \mathrm{U} / \mathrm{mL} / \mathrm{min})$ after 36 hours of incubation at $37^{\circ} \mathrm{C}, \mathrm{pH} 7.0$. It was also found that amylase from intracellular mutant strain had maximum activity; on the other side parental strain had maximum activity with an extracellular enzyme. Optimized temperature, $\mathrm{pH}$ and salt concentration revealed that the intracellular amylase from mutant strain had the maximum activity of $978 \mathrm{U} / \mathrm{mL} / \mathrm{min}, 985 \mathrm{U} / \mathrm{mL} / \mathrm{min}, 960 \mathrm{U} / \mathrm{mL} / \mathrm{min}$ respectively. Varying the source of carbon in the medium had a significant impact on enzyme activity. Metalloenzymes like amylases were reported to have strong activity towards metal ions, so amylase activity was analysed by adding different metal ions in the medium and found that calcium ions strongly promoted amylase activity and $\mathrm{Fe}^{2+}, \mathrm{Zn}^{2+}, \mathrm{Cu}^{2+}, \mathrm{Mg}^{2+}$ inhibited the activity. SDS-PAGE results showed that the molecular weight of isolated amylase to be approximately $55.0 \mathrm{kDa}$. Our study showed the capability of mutant B. tequilensis strain to produce double the amount of intracellular amylase than the parental strain.
\end{abstract}

Keywords: Amylolytic, mutagenesis, metalloenzymes, metal ions, zymogram

\section{INTRODUCTION}

Amylases are extracellular enzymes which hydrolyze the alpha 1, 4 glycosidic linkages of starch into sugars. Based on the cleavage site, amylase was classified into three types namely $\alpha$ - amylase, $\beta$ - amylase and $\gamma$ - amylase. Among them, $\alpha$ amylase is one of the significant industrial enzymes which are widely utilized for the purpose of brewing, baking, textile and detergent (Gupta et al., 2003). The biologically active enzymes are immensely present in natural resources such as plants, animals and microorganisms (Mageswari et al., 2012) of which microbial source plays a vital role since it can be produced in huge quantity meeting the demands of the market (Pandey et al., 2000). Bacillus tequilensis is a Grampositive, motile rods, produces central endospore in unswollen sporangia and its pathogenicity was undetermined (Gatson et al., 2006). Several studies on ultraviolet (UV) light have been reported to be mutagenic in a variety of organisms. The impact of UV radiations on alpha amylase producing ability of Bacillus species were studied earlier and attempts have been made for the overproduction of microbial enzyme by induced mutagenesis (Demirkan, 2011). The increase in amylase activity after exposing to UV light may be due to the changes in the promoter zone of a gene encoding for this enzyme and also the transcription of mRNA corresponding to the enzyme might have deregulated (De Nicolas-Santiago et al., 2006). The impact of ultraviolet radiations on Bacillus tequilensis producing $\alpha$-amylase was studied for the first time and the comparison of mutant and wild (parental) strain for increased $\alpha$-amylase activity was performed.

\section{MATERIALS AND METHODS}

\section{Sample collection}

Samples were collected from the coastal environment in Pudukkottai district, $\left(10^{\circ} 1\right.$ ' 12" North, $79^{\circ} 13^{\prime} 35^{\prime \prime}$ East) Tamil Nadu, India. Under sterile conditions, mud samples were collected and the samples were transferred to the laboratory and stored at $-20^{\circ} \mathrm{C}$ until further processing. The samples were collected from three different spots; [I] from the top layer (PDU-1), [II] from $10 \mathrm{~cm}$ depths (PDU-2) and [III] near the trees (PDU-3).

\section{Isolation, screening and identification of $\alpha$-amylase producer}

Collected samples were used for the isolation of amylase producing bacteria Samples were processed by taking one gram of mud sample suspended in $9.0 \mathrm{~mL}$ of sterile water and agitated for a min. $0.1 \mathrm{~mL}$ of the suspended sample was spread plated onto nutrient starch agar $(2.0 \%$ starch, $0.75 \%$ peptone, $0.5 \%$ beef extract, $0.5 \% \mathrm{NaCl}, 1.8 \%$ agar) and incubated at $37^{\circ} \mathrm{C}$ for 24 hours. To identify the amylolytic bacteria, plates were overlaid with iodine reagent $\left(0.01 \mathrm{M} \mathrm{I}_{2}-\mathrm{KI}\right)$. Based on the starch hydrolysis properties, isolates were identified by the clear zone formed around the isolates. All the isolates that produced a clear zone of hydrolysis (Amy+ and Amy-) were further selected and screened for amylase production. Selected positive isolates (Amy+) were sub-cultured twice for purity and pre-cultures were maintained in nutrient agar slants $\left(-20^{\circ} \mathrm{C}\right)$. Single selected isolate B- PDU $2 / 2$ was further identified by $16 \mathrm{~S}$ rRNA sequencing. DNA was isolated using Hi-media bacterial DNA mini-prep kit as per manufacturer's protocol and amplified using universal 16S rRNA primers; 27F: 5' AGAGTTTGATC MTGGCTCAG- 3' and 1492R: 5' CGGTTACCTTGTTACGACTT- 3' (Prasanth et al., 2016). Species level identification was done at www.ncbi.nlm.nih.gov/BLAST/ and BLAST nucleotide sequence similarity with $98 \%$ or above was deemed as sufficient for species identification.

\section{Inoculum and crude enzyme preparation}

Inoculum preparation was done by inoculating overnight grown culture from starch agar plates into $50 \mathrm{~mL}$ of starch broth and incubated at $37^{\circ} \mathrm{C}$ for 24 hours. 
Exponential phase was achieved that contained $3.0 \times 10^{8} \mathrm{CFU} / \mathrm{mL}$ and suitable volume from this suspension was used for the tests. To prepare crude enzymes, inoculated overnight grown cultures in starch broth were centrifuged at 10,000 rpm for $15 \mathrm{~min}$ and the supernatant was used as a crude enzyme for the enzyme assay for determination of activity.

\section{Enzyme assay}

The enzyme activity was assayed by using the DNS method. Briefly, a reaction mixture contained $0.5 \mathrm{~mL}$ crude enzyme solution and $0.5 \mathrm{~mL}$ soluble starch (1 $\mathrm{g} / 100 \mathrm{~mL}$ - prepared using $0.01 \mathrm{M}$ phosphate buffer) that was incubated for $5 \mathrm{~min}$ and reducing sugar was measured. The reaction mixture without crude enzyme served as a control (Miller, 1959). One unit of amylase activity is defined as the amount of enzyme that produces one micromole of reducing sugar in one minute at a constant temperature using soluble starch as substrate. Lowry's protein estimation method was used for total protein content determination (Lowry et al. 1951).

\section{Mutagenic studies}

The grown overnight bacterial culture was centrifuged at $10,000 \mathrm{rpm}$ for $15 \mathrm{~min}$ and the bacterial cells were resuspended in 50 millilitres of peptone water and further diluted to $10^{6}$ times and dilutions were plated, that served as a control. Ten millilitres from the diluted culture was transferred to another sterile petri plate Mutagenesis by UV rays was studied by exposing the petri plates at differen time intervals (30s, 60s, 90s and 120s) under the UV lamp. After exposing to predetermined time intervals, $0.5 \mathrm{~mL}$ of bacterial culture was plated onto a starch agar plate and incubated at $37^{\circ} \mathrm{C}$ for $24-48 \mathrm{hrs}$ and further used for enzyme assay. The intracellular and extracellular activity of amylase was studied for both parental and mutant strains. To extract the intracellular amylase, cells were sonicated and centrifuged to collect the intracellular crude enzyme.

\section{Optimization of physiochemical and nutritional parameters}

Parameters that can influence the amylase production were optimized independently and individually. So, optimization conditions were used subsequently for all the experiments both for the parental and mutant strain. For temperature optimization, the basal medium was inoculated and incubated at 35 , $40,45,50,55^{\circ} \mathrm{C}$ under standard assay conditions and for every 12 hours samples were withdrawn to study the effect of the incubation period. For $\mathrm{pH}$ optimization, the culture medium was prepared with variable $\mathrm{pH} 5.0$ to 9.0 and assayed for standard assay conditions. The growth medium was supplemented with varying concentrations of starch (1\% to $4 \%)$ and also with different carbon source including maltose, sucrose, lactose, glucose and fructose for enzyme production To analyse the effect of salt concentration on enzyme production varying concentrations of sodium chloride ( $1 \%$ to $6 \%$ ) was used in the growth medium.

\section{Effect of metal ions on enzyme activity}

Metal ions have a strong influence on enzyme production and activity. To investigate the role of metal ions towards amylase activity various metal ions, $\mathrm{FeSO}_{4}, \mathrm{KCl}, \mathrm{CuSO}_{4}, \mathrm{ZnSO}_{4}, \mathrm{CaCl}_{2}, \mathrm{MgSO}_{4}$ were used at $25 \mathrm{mM}$ concentration. Different metal ions were added to the medium and enzyme activity was assayed in standard assay conditions (Demirkan, 2011).

\section{SDS-PAGE and zymogram analysis}

The molecular weight of the enzyme was estimated by sodium dodecyl sulphate polyacrylamide gel electrophoresis. The prepared enzyme from both parental and mutant strain was loaded along with protein marker in $12 \%$ gel and purity of the protein was confirmed (Laemmli, 1970). Approximate molecular weight was determined after staining with $\mathrm{CBB}$ and de-staining. Zymogram was done with native-PAGE by incubating in $1 \%$ starch for 1 hour and staining with iodine solution.

\section{Kinetic properties of $\alpha$-amylase and statistical analysis}

To assess the kinetic properties, hydrolysis by DNS method with differen concentrations of starch was used. $\mathrm{K}_{\mathrm{m}}$ and $\mathrm{V}_{\max }$ were calculated using the Michaelis-Menten equation. All the experiments were performed in triplets and the resulting values were presented as the mean of three independent observations. GraphPad Prism 5.0 software was used for calculating meanstandard deviation for each experimental result.

\section{RESULTS AND DISCUSSION}

Isolation, screening and identification of amylase producing bacterial cultures
Bacterial isolates producing clear amylolytic zones were initially identified by staining the plates with iodine solution. 16 isolates were found to produce clear zones in the starch-iodine plate out of which six isolates produced $>1.7 \mathrm{~cm}$ zones that are considered as significant. Selected isolates were reassessed for the zone of clearance by a well-diffusion method. Isolates that showed the constant zone of clearance within 5-6 hours of incubation at $37^{\circ} \mathrm{C}$ was selected for further analysis. Isolate B-PDU2/2 was selected and found to be Gram-positive, motile and facultative aerobe. It was found to grow at $\mathrm{pH} 6.0,7.0,8.0$ and salt concentrations up to $7 \%$. Analysis of $16 \mathrm{~S}$ rRNA sequence revealed its $98 \%$ homology with Bacillus tequilensis (KT760402). 16S rRNA is a powerful molecular marker for species-specific identification at the microscopic level was provided earlier (Tiwari et al., 2014).

\section{Medium selection and mutagenic experiments}

Growth curve experiments revealed that B-PDU2/2 had a steady stationary phase after 30 hours in starch broth while other nutrient broths had 24 hours. Extracellular amylase activity was found to have maximum activity/productivity at 36 hours in starch broth (Fig.2). Mutagenic studies with UV exposure at different time intervals revealed that after $60 \mathrm{secs}$ of UV exposure maximum amylase activity was achieved in the intracellular enzyme (Fig.1). Interestingly, the parental strain had a maximum activity of $418 \mathrm{U} / \mathrm{mL} / \mathrm{min}$ with extracellular enzyme whereas intracellular enzyme from mutant strain had a maximum activity of $868 \mathrm{U} / \mathrm{mL} / \mathrm{min}$. Hence, the starch broth with the extracellular enzyme from parental strain and intracellular enzyme from a mutant strain (60 secs of UV exposure) was further taken for optimization. Similarly, higher activity was observed in the mutant strain than in its parental strain in B. subtilis (Zhao and Qirong, 1994; Allan et al., 1997). In some cases, UV mutagenesis also inhibited the activity of parental strain that showed lower activity than parental strain in contrast chemical mutagenesis had higher activity (Haq et al., 1997).

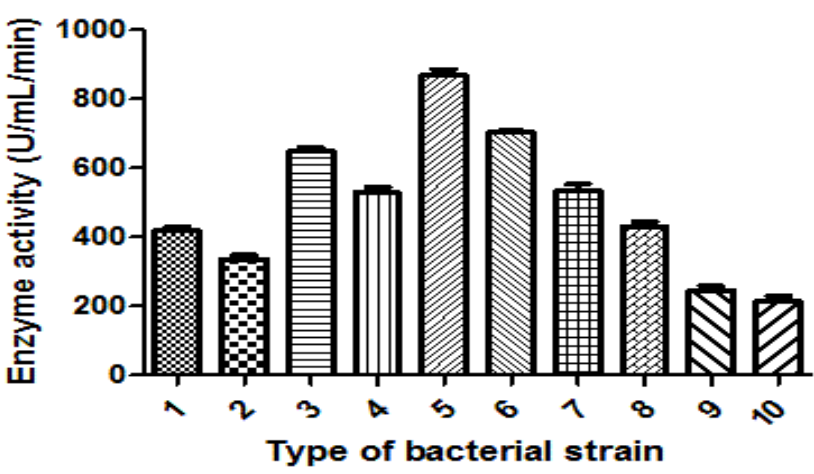

Figure 1 Comparison of amylase produced by parental and wild type strains of Bacillus tequilensis in starch medium at $45^{\circ} \mathrm{C}, \mathrm{pH}$ 7. 1-parental extracellular, 2parental intracellular, 3-after 30s of UV exposure intracellular, 4-after 30s of UV exposure extracellular, 5-after 60s of UV exposure intracellular, 6-after 60s of UV exposure extracellular, 7-after 90s of UV exposure intracellular, 8-after 90s of UV exposure extracellular, 9-after 120s of UV exposure intracellular, 10-after 120 s of UV exposure extracellular.
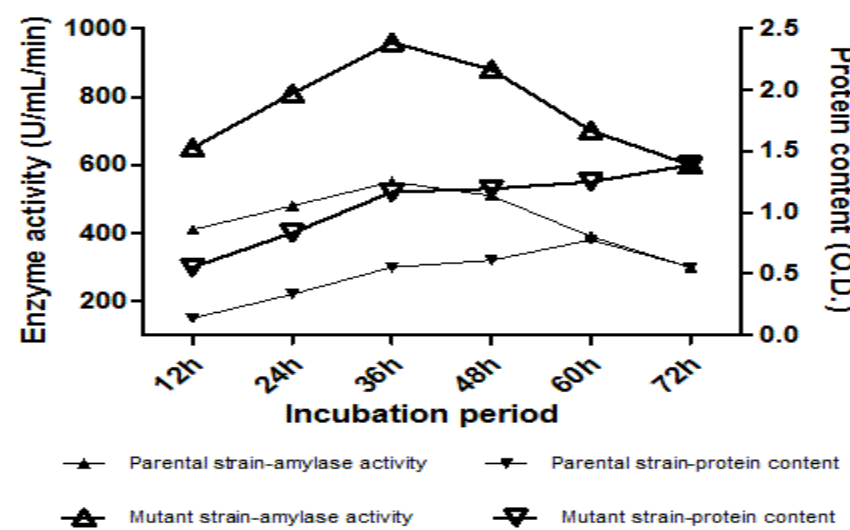

Figure 2 Total protein content of Bacillus tequilensis compared with production of amylase in mutant (60 sec UV exposure, intracellular) and parental strain (extracellular). Fermentation period analysis was made in starch medium at $45^{\circ} \mathrm{C}$, $\mathrm{pH} 7.0$.

\section{Effect of different temperature}

Evaluation of amylase activity at different temperatures $\left(35-65^{\circ} \mathrm{C}\right)$ showed that both parental extracellular and mutant intracellular enzyme had a maximum activity of 522 and $978 \mathrm{U} / \mathrm{mL} / \mathrm{min}$ at $45^{\circ} \mathrm{C}$ respectively. It also showed that 
increase in temperature gradually decreases the activity of amylase (Fig.3,4). The temperature was also found to have a profound effect on Bacillus sp. in amylase production (Raul et al., 2014). An incubation temperature of $37^{\circ} \mathrm{C}$ was optimum for most Bacillus sp. to produce maximum activity of amylase though some thermostable amylase can sustain temperatures up to $45-90^{\circ} \mathrm{C}$ (Sodhi et al., 2005; Asgher et al., 2007).

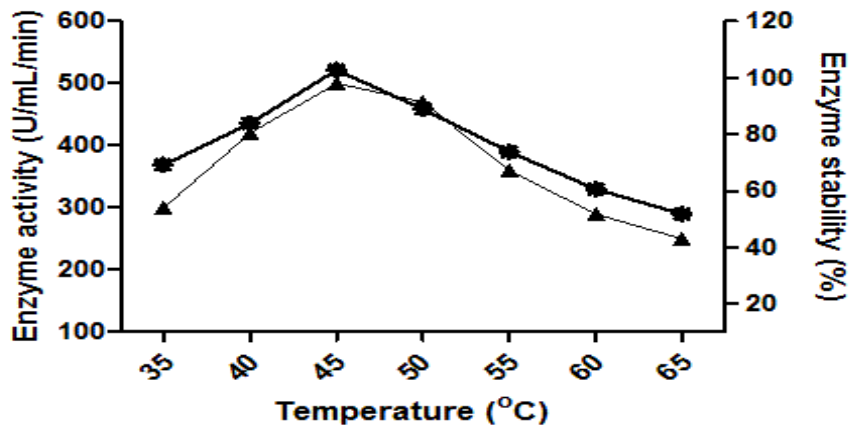

Enzyme activity $(\mathrm{U} / \mathrm{mL} / \mathrm{min}) \_$Enzyme stability $(\%)$

Figure 3 Effect of different temperature on enzyme activity and enzyme stability of parental strain (extracellular). Each individual point is the representation of mean with standard deviation for each experimental result done in triplicates.

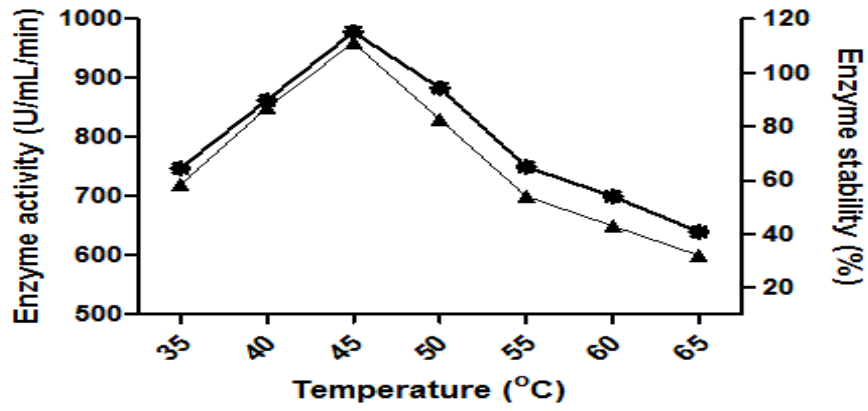

Enzyme activity $(\mathrm{U} / \mathrm{mL} / \mathrm{min})-$ Enzyme stability $(\%)$

Figure 4 Effect of different temperature on enzyme activity and enzyme stability of mutant strain (60 sec of UV exposure, intracellular). Each individual point is the representation of mean with standard deviation for each experimental result done in triplicates. Mutant strain was found to have more enzyme activity as well as production rate comparing with parental strain.

\section{Effect of different $\mathrm{pH}$}

Optimization with different $\mathrm{pH}(5.0-9.0)$ revealed that both extracellular and intracellular amylase were not stable at stronger acidic as well as alkaline conditions. Also, $\mathrm{pH}$ of the medium had a strong influence on enzyme activity (Fig.5,6). At neutral pH 7.0 extracellular amylase of parental strain had an activity of $538 \mathrm{U} / \mathrm{mL} / \mathrm{min}$ and intracellular amylase from the mutant strain $(985$ $\mathrm{U} / \mathrm{mL} / \mathrm{min}$ ) had maximum activities. Bacillus sp. used for industrial amylase production was found to have optimum $\mathrm{pH}$ of 6.0 to 7.0 (Haq et al., 2010) Variation in $\mathrm{pH}$ also indicates the initiation and end of enzyme synthesis (Friedrich et al., 1989). The incubation period of 36 hours was found to have maximum enzyme activity (fig.2) and increase in incubation time decreases the enzyme activity that may be due to an interaction of synthesized enzyme with other components in the medium (Ramesh and Lonsane, 1987).

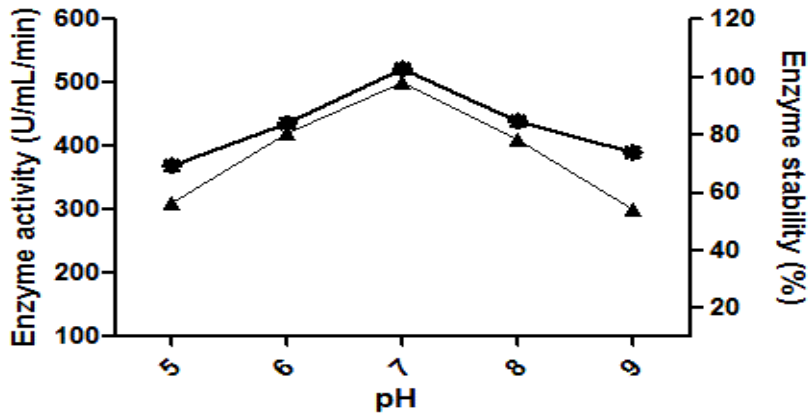

Enzyme activity $(\mathrm{U} / \mathrm{mL} / \mathrm{min})-$ Enzyme stability (\%)

Figure 5 Effect of different pH on enzyme activity and enzyme stability of parental strain (extracellular). Each individual point is the representation of mean with standard deviation for each experimental result done in triplicates.

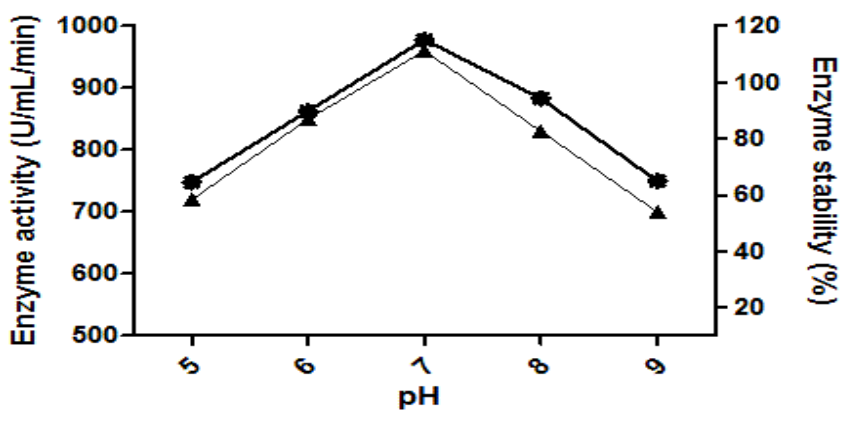

Enzyme activity $(\mathrm{U} / \mathrm{mL} / \mathrm{min}) \star$ Enzyme stability $(\%)$

Figure 6 Effect of different $\mathrm{pH}$ on enzyme activity and enzyme stability of mutant strain (60 sec of UV exposure, intracellular). Each individual point is the representation of mean with standard deviation for each experimental result done in triplicates. Mutant strain was found to have more enzyme activity as well as production rate compared to parental strain.

\section{Effect of salt concentration on enzyme production}

Enzyme activity was found to be decreasing as salt concentration $(\mathrm{NaCl})$ increases from $1 \%$. Though bacterial growth was observed at higher salt concentrations up to $7 \%$ enzyme activity was inhibited with an increase in salt concentration (Fig.7). Accordingly, the parental strain had maximum activity at $1 \%(510 \mathrm{U} / \mathrm{mL} / \mathrm{min})$ as same as the mutant strain $(960 \mathrm{U} / \mathrm{mL} / \mathrm{min})$.

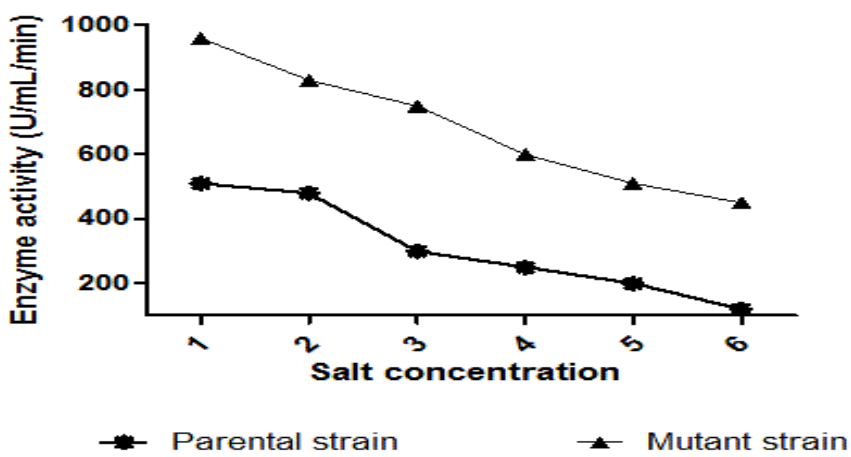

Figure 7 Effect of different salt concentration $(\mathrm{NaCl})$ on enzyme activity of parental strain (extracellular) and mutant strain $(60 \mathrm{sec}$ of UV exposure intracellular). Each individual point is the representation of mean with standard deviation for each experimental result done in triplicates.

\section{Effect of different carbon sources}

The starch broth was found to give maximum enzyme activity/production. Any increase or decrease in starch concentration (1\% to $4 \%$ ) had a lesser effect on enzyme activity on both parental and mutant strains $(510 \mathrm{U} / \mathrm{mL} / \mathrm{min}$ and 960 $\mathrm{U} / \mathrm{ml} / \mathrm{min}$ ) whereas $2 \%$ starch had maximum activity after 36 hours of incubation (Fig.8). Supplemented with other carbon sources had affected the enzyme activity in that case glucose and fructose gave lesser enzyme activity than maltose, sucrose and lactose (maltose>lactose $>$ sucrose $>$ glucose $>$ fructose). Some reports found maltose to be a good inducer of amylase activity (Goto et al., 1988; Narang and Satyanarayana, 2001). In some cases, glucose was found to repress amylase activity and also glucose was reported to be an inducer (Normurodova et al., 2007). Varying starch concentration was also reported influencing the enzyme activity (Tiwari et al., 2014). 


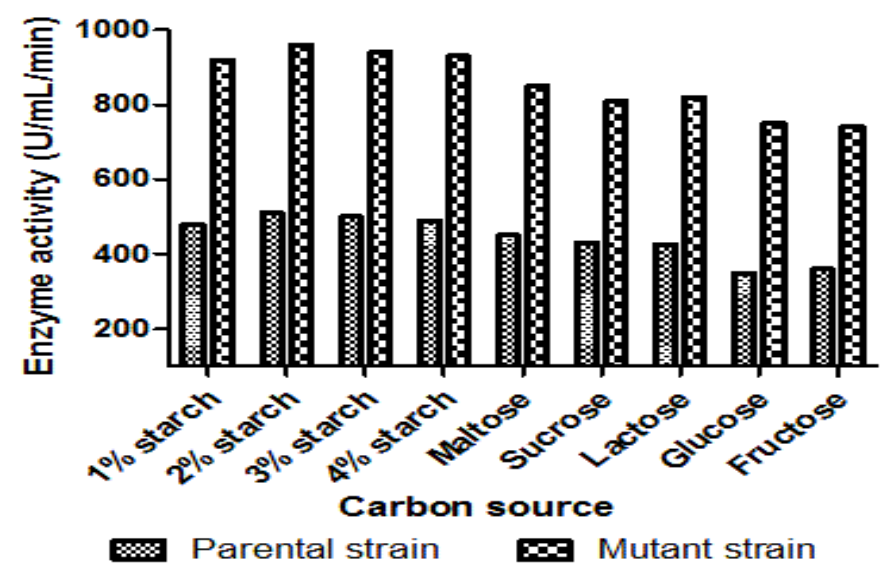

Figure 8 Effect of different carbon sources on enzyme activity of parental strain (extracellular) and mutant strain (60 sec of UV exposure, intracellular). Each individual bars are the representation of mean with standard deviation for each experimental result done in triplicates.

\section{Effect of different metal ions}

For the study of metal ions, $25 \mathrm{mM}$ each of $\mathrm{FeSO}_{4}, \mathrm{KCl}, \mathrm{ZnSO}_{4}, \mathrm{CaCl}_{2}, \mathrm{CuSO}_{4}$ $\mathrm{MgSO}_{4}$ were used in the medium at optimum temperature, $\mathrm{pH}$ and incubation period. Out of which calcium ions was found to be best for amylase production. Other ions $\mathrm{Fe}^{2+}, \mathrm{Zn}^{2+}, \mathrm{Cu}^{2+}, \mathrm{Mg}^{2+}$ had slightly decreased the enzyme activity compared to $\mathrm{Ca}^{2+}$ ions (Fig.9). It was found that calcium ions increase the activity of amylase compared to control (without ions). The catalytic activity of amylolytic enzymes can be affected by mono- and divalent metal ions but this metalloenzyme has up to six $\mathrm{Ca}^{2+}$ atoms at its active site so that can be activated by calcium ions (Asgher et al., 2007; Normurodova et al., 2007).

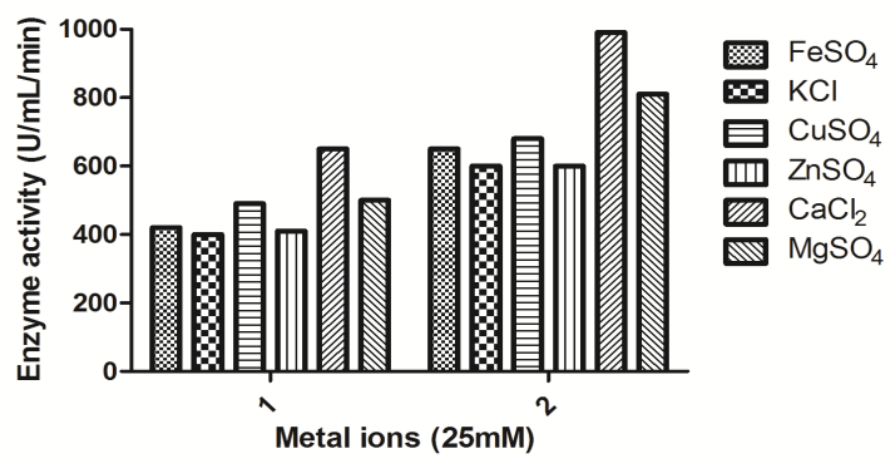

Figure 9 Effect of different metal ions on enzyme activity of parental strain (extracellular) and mutant strain (60 sec of UV exposure, intracellular). 1Parental strain and 2- Mutant strain. Each individual bars are the representation of mean with standard deviation for each experimental result done in triplicates.

\section{Stability of amylase and kinetic properties}

Stability of enzyme was particularly important for its application in industries. Amylase produced from $B$. tequilensis was found to be active and stable at $45^{\circ} \mathrm{C}$ and $\mathrm{pH} 7.0$ that correlates with its higher production rate (Fig.3,4,5,6). Protein content and amylase activity were found to be strongly influenced by the temperature and $\mathrm{pH}$, although the temperature was controlled by incubation conditions and $\mathrm{pH}$ in the medium. Amylase from Bacillus spp. was also reported being stable at acidic as well as alkaline conditions (Demirkan et al., 2005; Demirkan, 2011). Michaelis-Menten kinetic parameters were calculated to be $1.27 \mathrm{mg} / \mathrm{mL}$ and $1.97 \mathrm{mg} / \mathrm{mL}$ for $\mathrm{K}_{\mathrm{m}}$ and $121 \mathrm{U} / \mathrm{mL}$ and $187 \mathrm{U} / \mathrm{mL}$ for $\mathrm{V}_{\max }$ respectively.

\section{SDS-PAGE analysis and zymography}

The molecular weight was determined to be approximately $55.0 \mathrm{kDa}$ (Fig.10) and a single band in SDS-PAGE confirmed the purity of amylase produced from $B$. tequilensis. Alpha-amylase from Bacillus spp. was found to have a molecular weight ranging from $50-60 \mathrm{kDa}$. A similar study using B. tequilensis reported molecular weight to be $67 \mathrm{kDa}$ for synthesized amylase (Tiwari et al., 2014) Zymogram results also indicated the presence of an amylolytic enzyme that hydrolysis the starch. The clear zone indicates the presence of an enzyme (protein) in zymography (Fig.11).

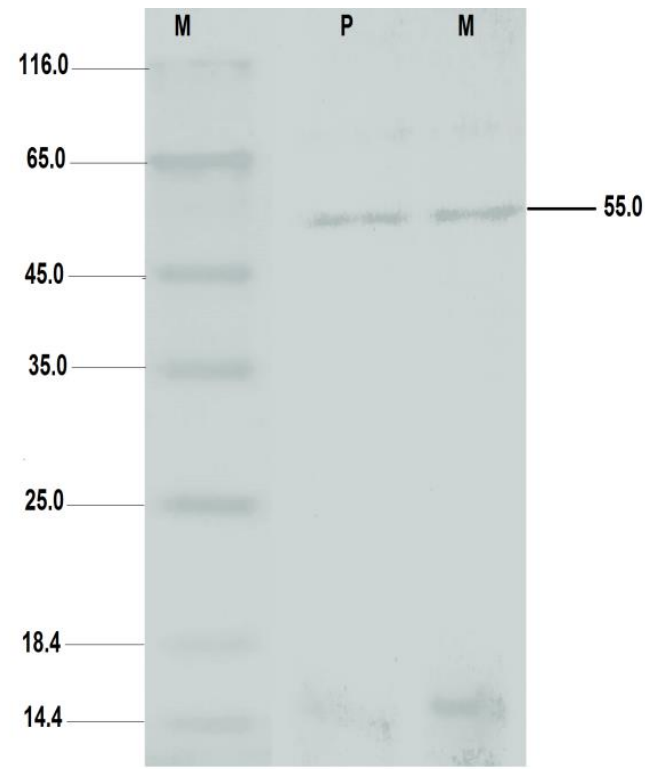

Figure 10 SDS-PAGE results for amylase from parental and mutant strains of Bacillus tequilensis. M- Protein marker, P-extracellular amylase from parental strain, M- intracellular amylase from mutant strain. Molecular weights were represented in $\mathrm{kDa}$ and produced amylase was $\sim 55.0 \mathrm{kDa}$.

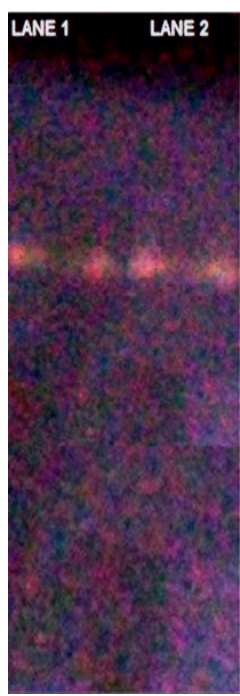

Figure 11 Zymogram result for amylase from B. tequilensis in native PAGE that hydrolysed soluble starch. A clear white region around the black background indicates the amylolytic activity. Lane-1; extracellular amylase from parental strain, Lane-2; intracellular amylase from mutant strain.

\section{Conflict of interests}

The authors declare that there is no conflict of interests regarding the publication of this paper.

\section{REFERENCES}

Allan, S., Torbenvedel, B., \& Henrick, B. F. (1997). Recombinant alpha amylase mutants and their use in textile desizing starch liquification and washing. PTC. Int. Appl, 12(5), 205-210.

Asgher, M., Asad, M. J., Rahman, S. U., \& Legge, R. L. (2007). A thermostable $\alpha$-amylase from a moderately thermophilic Bacillus subtilis strain for starch processing. Journal of Food Engineering, 79(3), 950-955. http://dx.doi.org/10.1016/j.jfoodeng.2005.12.053

Demirkan, E. (2011). Production, purification, and characterization of alphaamylase by Bacillus subtilis and its mutant derivates. Turkish Journal of Biology, 35(6), 705-712. http://dx.doi.org/10.3906/biy-1009-113

Demirkan, E. S., Mikami, B., Adachi, M., Higasa, T., \& Utsumi, S. (2005). $\alpha$ Amylase from B. amyloliquefaciens: purification, characterization, raw starch degradation and expression in E. coli. Process Biochemistry, 40(8), 2629-2636. http://dx.doi.org/10.1016/j.procbio.2004.08.015

Friedrich, J., Cimerman, A., \& Steiner, W. (1989). Submerged production of pectolytic enzymes by Aspergillus niger: effect of different aeration/agitation regimes. Applied Microbiology and Biotechnology,31(5-6), 490-494. http://dx.doi.10.1007/BF00270782 
Gatson, J. W., Benz, B. F., Chandrasekaran, C., Satomi, M., Venkateswaran, K., \& Hart, M. E. (2006). Bacillus tequilensis sp. nov., isolated from a 2000-year-old Mexican shaft-tomb, is closely related to Bacillus subtilis. International Journal of Systematic and Evolutionary Microbiology, 56(7), 1475-1484 http://dx.doi.org/10.1099/ijs.0.63946-0

Goto, C. E., Barbosa, E. P., Kistner, L. C., Moreira, F. G., Lenartovicz, V., \& Peralta, R. M. (1998). Production of amylase by Aspergillus fumigatus utilizing $\alpha$-methyl-D-glycoside, a synthetic analogue of maltose, as substrate. FEMS Microbiology Letters, 167(2), 139-143. http://dx.doi.org/10.1111/j.1574 6968.1998.tb13219.x

Gupta, R., Gigras, P., Mohapatra, H., Goswami, V. K., \& Chauhan, B. (2003) Microbial $\alpha$-amylases: a biotechnological perspective. Proces Biochemistry, 38(11), 1599-1616.

Haq, I., Ali, S., Javed, M. M., Hameed, U., Saleem, A., Adnan, F., \& Qadeer, M. A. (2010). Production of alpha amylase from a randomly induced mutant strain of Bacillus amyloliquefaciens and its application as a desizer in textile industry. Pakistan Journal of Botany, 42(1), 473-484.

Laemmli, U. K. (1970). Cleavage of structural proteins during the assembly of the head of bacteriophage T4. Nature, 227, 680-685. http://dx.doi.org/10.1038/227680a0

Lowry, O. H., Rosebrough, N. J., Farr, A. L., \& Randall, R. J. (1951). Protein measurement with the Folin phenol reagent. Journal of Biological Chemistry, 193(1), 265-275.

Mageswari, A., Subramanian, P., Chandrasekaran, S., Sivashanmugam, K., Babu, S., \& Gothandam, K. M. (2012). Optimization and immobilization of amylase obtained from halotolerant bacteria isolated from solar salterns. Journal of Genetic Engineering and Biotechnology, 10(2), 201-208. http://dx.doi.org/doi.org/10.1016/j.jgeb.2012.09.001

Miller, G. L. (1959). Use of dinitrosalicylic acid reagent for determination of reducing sugar. Analytical Chemistry, 31(3), 426-428.

Narang, S., \& Satyanarayana, T. (2001). Thermostable $\alpha$-amylase production by an extreme thermophile Bacillus thermooleovorans. Letters in Applied Microbiology, 32(1), 31-35. http://dx.doi.org/10.1111/j.1472-765X.2001.00849.x Nicolás-Santiago, D., Regalado-González, C., García-Almendárez, B., Fernández, F. J., Téllez-Jurado, A., \& Huerta-Ochoa, S. (2006). Physiological, morphological, and mannanase production studies on Aspergillus nigeruam-gs 1 mutants. Electronic Journal of Biotechnology, 9(1) http://dx.doi.org/10.4067/S0717-34582006000100008

Normurodova, K. T., Nurmatov, S. K., Alimova, B. K., Pulatova, O. M., Akhmedova, Z. R., \& Makhsumkhanov, A. A. (2007). Isolation and characteristics of highly active $\alpha$-amylase from Bacillus subtilis-150. Chemistry of Natural Compounds, 43(4), 454-457. http://dx.doi.org/10.1007/s10600-007$\underline{0159-1}$

Pandey, A., Nigam, P., Soccol, C.R., Soccol, V.T., Singh, D., \& Mohan, R. (2000). Advances in microbial amylases. Biotechnology and Applied Biochemistry, 31(Pt 2), 135-52.

Prasanth, M., Bozdogan, B., Gothandam K. M., Sivashanmugam, K., \& Nachimuthu, R. (2016). A novel $\alpha$-amylase producing Bacillus drentensis isolated from coastal mud samples. Asian Journal of Biological and Life Sciences, 5(2), 173-178.

Ramesh, M. V., \& Lonsane, B. K. (1987). A novel bacterial thermostable alphaamylase system produced under solid state fermentation. Biotechnology Letters, 9(7), 501-504. http://dx.doi.org/10.1007/BF01027460

Raul, D., Biswas, T., Mukhopadhyay, S., Kumar Das, S., \& Gupta, S. (2014). Production and partial purification of alpha amylase from Bacillus subtilis (MTCC 121) using solid state fermentation. Biochemistry Research International, 2014. http://dx.doi.org/10.1155/2014/568141

Sodhi, H. K., Sharma, K., Gupta, J. K., \& Soni, S. K. (2005). Production of a thermostable $\alpha$-amylase from Bacillus sp. PS-7 by solid state fermentation and its synergistic use in the hydrolysis of malt starch for alcohol production. Process Biochemistry, 40(2), 525-534. http://dx.doi.org/10.1016/j.procbio.2003.10.008

Tiwari, S., Shukla, N., Mishra, P., \& Gaur, R. (2014). Enhanced production and characterization of a solvent stable amylase from solvent tolerant Bacillus tequilensis RG-01: thermostable and surfactant resistant. The Scientific World Journal, 2014. http://dx.doi.org/10.1155/2014/972763

Qirang, J., \& Zhao, W. (1994). Selection and breeding of a high productivity strain of alpha amylase from multi resistant mutant of Bacillus. Wuxi Qinggongyo Xueguan Xuebae, 13, 21-26. 